\title{
The NE subarctic Pacific in winter: II. Biological rate processes
}

\author{
P. W. Boyd ${ }^{1, *}$, F. A. Whitney ${ }^{2}$, P. J. Harrison ${ }^{1}$, C. S. Wong ${ }^{2}$ \\ 'Department of Oceanography, University of British Columbia, Vancouver, British Columbia, Canada V6T 1Z4 \\ ${ }^{2}$ Center for Ocean Climate Chemistry, Institute of Ocean Sciences, Sidney, British Columbia, Canada V8L 4 B2
}

\begin{abstract}
In over $20 \mathrm{yr}$ of biological observations, with the exception of primary production data, no rate process measurements have been made during winter in the NE Pacific. In this paper, the first suite of detailed biological rate process measurements are presented. Rates of primary production, phytoplankton growth, microzooplankton grazing and bacterial production are lower during winter at Ocean Station Papa (OSP) off northwestern Canada than those observed during summer. Despite the reduced rates, there is sufficient net primary production to maintain a supply of carbon to the microbial food web during the overwintering period. As winter stocks of autotrophs and microheterotrophs at OSP have been observed on occasion to be comparable to those observed in summer, a reduced turnover of winter stocks is implied from the observed depression of biological rates. In winter, according to our limited observations, phytoplankton growth rates may be controlled by available irradiance, whereas heterotrophic bacterial production is likely to be controlled by water temperature and substrate limitation. Microzooplankton grazing rates may be primarily limited by temperature, since observed prey concentrations are not reduced compared to summer Despite the reduced microzooplankton grazing rates, limited winter observations suggest that their biomass remains comparable to that observed during summer. Mesozooplankton are present in low numbers in the upper water column during winter at OSP. Thus, the maintenance of high microzooplankton stocks during winter, a requirement in order to prevent the development of the spring bloom, may result from low mesozooplankton grazing pressure rather than from low dispersal due to insufficient strong mixing. The life cycle of the mesozooplankton, in addition to the shallow winter mixed layer depth in the NE subarctic Pacific, may be an important factor in the prevention of a spring bloom.
\end{abstract}

KEY WORDS: Subarctic Pacific $\cdot$ Winter $\cdot$ Rate processes $\cdot$ Primary production $\cdot$ Grazing

\section{INTRODUCTION}

The NE subarctic Pacific provides one of the best resolved time series for an open ocean temperate water region (Banse 1990). However, despite over 20 yr of biological observations, most of the data collected have focused on the biomass/abundances of the components within the phytoplankton and zooplankton (Parslow 1981). Until recently, little was known about the standing stocks of the microheterotrophs over the important winter period (Boyd et al. 1995, this issue).

The efforts of the SUPER program (see Boyd et al. 1995 ) in the mid 1980s changed our perception of the structure and function of this pelagic ecosystem

•E-mail:pboyd@unixg.ubc.ca through a series of extensive biomass and rate process measurements (summarized by Miller 1993). However, that program was conducted between late spring and late summer (Miller et al. 1991) and thus no rate process measurements were made during the winter period at Ocean Station Papa (OSP) off NW Canada. The only rate process data available during the winter period are for primary production, which was measured using short term, on-deck incubations from noon to $18: 00 \mathrm{~h}$ (local time) on the weatherships at OSP between 1964 and 1981 (Parslow 1981), and more recently with in situ short term incubations from dawn to local noon at OSP by Wong et al. (1995).

Long time series data from OSP have demonstrated the lack of a well-defined annual spring bloom (Parslow 1981, Frost 1991), in contrast to the subarctic 
Atlantic (Parsons \& Lalli 1988). These differences between the pelagic ecology of the subpolar NE Atlantic and NE Pacific have made the structure and function of these pelagic ecosystems of interest to modellers who wish to study the magnitude of the coupling between mesozooplankton and phytoplankton. Modelling studies (Evans \& Parslow 1985, Fasham 1995) and recent hypotheses (Miller et al. 1991) have suggested that the winter period is important in the dynamics of these ecosystems. Evans \& Parslow (1985) and Fasham (1995) were able to model the seasonal cycle of phytoplankton and zooplankton at OSP and to demonstrate that it was necessary to have a mean photosynthetic rate in the mixed layer that was high enough to support sufficient zooplankton growth during late winter. Thus, at the time of the spring stratification, the zooplankton grazing rates should match algal growth rates and prevent the development of the spring bloom. Evans \& Parslow (1985) argued that this would not happen in the north Atlantic where the much deeper mixed layer depths would not allow net phytoplankton growth to occur.

Miller et al. (1991) concurred with this hypothesis, but linked it with the necessity for high specific growth rates typical of microzooplanktonic herbivores. From the synthesis of the SUPER program, Miller et al. (1991) developed a 'mixing and micrograzer' hypothesis, which suggested that the grazing capacity of microzooplankton was comparable to the growth rate of phytoplankton and that physical mixing is insufficient to 'sweep away' the phytoplankton and microzooplankton, thereby controlling phytoplankton biomass via grazing all year round. This hypothesis remains untested and requires data to examine the relationship between phytoplankton stocks and their protozoan grazers during the winter season. Although data are now available on winter autotrophic and heterotrophic stocks at OSP (Boyd et al. 1995), information on the dynamics of the phytoplankton/microzooplankton relationship during winter are required. In addition, little is known about what processes control the components of the pelagic microbial food web in the NE subarctic Pacific in winter.

The present study provides the first detailed biological rate process data set from the NE subarctic Pacific over the winter period and the opportunity to address the above questions.

\section{MATERIALS AND METHODS}

Data were obtained in the NE subarctic Pacific in March 1993 from OSP $\left(50^{\circ} \mathrm{N}, 145^{\circ} \mathrm{W}\right)$ and in February 1994 from Station P23 $\left(49^{\circ} 48^{\prime} \mathrm{N}, 142^{\circ} 27^{\prime} \mathrm{W}\right)$, around $200 \mathrm{~km}$ east of OSP. Underway fluorescence data from
March 1993 (P. W Boyd unpubl.) indicated little spatial variability along a $300 \mathrm{~km}$ transect eastwards from OSP. Due to adverse weather conditions during the February 1994 cruise and reduced personnel in March 1993, some data were not available for both years.

Size-fractionated primary production was estimated using 0.2 to $5.0 \mu \mathrm{m}, 5$ to $18 \mu \mathrm{m}$ and $>18 \mu \mathrm{m}$ size classes and the ${ }^{14} \mathrm{C}$ technique following Joint et al. (1993). Based on a prior underwater irradiance profile, seawater was collected from depths corresponding to approximately $100,55,30,10,3.5$ and $1 \% I_{0}$ using 301 (1993) and 101 (1994) pre-cleaned Go-Flo samplers (Martin \& Gordon 1988) and transferred to acidcleaned $60 \mathrm{ml}$ polycarbonate bottles. During the $24 \mathrm{~h}$ incubations, bottles with seawater inoculated with ${ }^{14} \mathrm{C}$ were held in a deck incubator at a range of irradiance conditions corresponding to the depths at which the samples were taken $\left(100,55,30,10,3.5\right.$ and $\left.1 \% I_{0}\right)$ using neutral density screens. Constant temperature was maintained with continuously flowing surface seawater Three light bottles and 1 dark bottle were placed under each screen. Rates in dark bottles were $<20 \%$ of light bottle rates and were subtracted from those obtained from the light bottles. In March 1993, an in situ incubation of 6 to 7 h duration was also performed, after Wong et al. (1995).

Microzooplankton grazing experiments were performed using the dilution technique of Landry (1993) at 4 dilutions $(22,44,66$ and $100 \%)$ and with 2 replicates at each dilution. Seawater from $10 \mathrm{~m}$ depth obtained with 301 (1993) and 101 (1994) pre-cleaned Go-Flo samplers was gently added to $4.5 \mathrm{l}$ acidcleaned polycarbonate bottles. Filtered seawater $(<0.2 \mu \mathrm{m})$ was also obtained from $10 \mathrm{~m}$ depth and pretreated after Landry et al. (1993). Microzooplankton grazing and apparent algal growth rates were calculated after Landry (1993) from $24 \mathrm{~h}$ experiments in the on-deck incubator, maintained at ambient seawater temperature and at $30 \% I_{0}$ using neutral density screens. The diluent was also incubated for $24 \mathrm{~h}$ in order to assess any growth of algal cells that had passed through the $0.2 \mu \mathrm{m}$ porosity filter (Li 1990). Bacterial production was estimated using the tritiated thymidine incorporation method of Fuhrman \& Azam (1982) modified after Bell (1993). Replicate $30 \mathrm{ml}$ samples of seawater from a subset of sampling depths used for primary production experiments were dispensed into aseptic plastic containers. The samples were incubated for $3 \mathrm{~h}$ in the water-cooled incubator described above.

In order to assess what factor(s) control phytoplankton standing stocks during winter in the NE subarctic Pacific, a 5 d bioassay was performed at Station P23 in February 1994 to investigate the relationship between iron supply, available irradiance and phytoplankton 
biomass. Seawater was collected from approximately $15 \mathrm{~m}$ depth using $10 \mathrm{l}$ pre-cleaned Go-Flo samplers (Martin \& Gordon 1988) and transferred to acidcleaned $25 \mathrm{l}$ polycarbonate carboys. Seawater only (25 l), and seawater with soluble iron (25 l), to give a final concentration of $4 \mathrm{nM} F e$ were added to control carboys and iron addition carboys, respectively. Iron was added in a 1:1.5 Fe:EDTA solution to ensure initial iron solubility, while not altering the overall metal speciation in the seawater sample (Coale 1991). All manipulations, including subsampling of the carboys were carried out in a portable positive-pressure laboratory. Carboys were held in a deck incubator at 30,20 and $10 \% I_{0}$ using neutral density screens and at constant temperature using continuously flowing surface seawater. The carboys were subsampled for size-fractionated chlorophyll a (chl a) at time zero and every day for the $5 \mathrm{~d}$ duration of the experiment. In order to estimate size-fractionated chlorophyll, phytoplankton were collected both under gravity on $18 \mu \mathrm{m}$ porosity polycarbonate filters and using $<100 \mathrm{~mm} \mathrm{Hg}$ vacuum on $5 \mu \mathrm{m}$ and $0.2 \mu \mathrm{m}$ porosity polycarbonate filters in a fractionation cascade (Joint \& Pomroy 1983).

$\mathrm{Chl}$ a was measured by in vitro fluorometry using a Turner Designs model 10 fluorometer (Parsons et al. 1984) calibrated with standards derived from commer- cially prepared chlorophyll (Sigma Chemical Company, St Louis, MO, USA), the concentration of which had been checked spectrophotometrically. On-deck incident photosynthetic active radiance (PAR) was measured as described by Boyd et al. (1995).

\section{RESULTS}

Surface PAR for March 1993 over a period of $4 \mathrm{~d}$ at OSP ranged between $<50$ and $900 \mu \mathrm{mol}$ photons $\mathrm{m}^{-2}$ $\mathrm{s}^{-1}$ over the period of daylight $(<12 \mathrm{~h})$. Daily irradiance totals of 18.3 to $21.2 \mathrm{~mol}$ photons $\mathrm{m}^{-2}$ were recorded between March 12 and 15 inclusive at OSP. Thus the mean irradiance was around $400 \mu \mathrm{mol} \mathrm{m}^{-2} \mathrm{~s}^{-1}$. No PAR data were available for the February 1994 cruise.

Rates of primary production from samples incubated

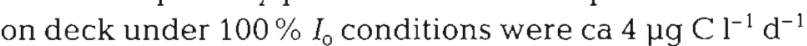
in March 1993 and were higher in February 1994 (ca $8 \mu \mathrm{g} \mathrm{l}^{-1} \mathrm{~d}^{-1}$; Fig. 1). In both studies, the maximum normalized photosynthetic rates ranged from 9.6 to $22.9 \mu \mathrm{g}$ $\mathrm{C}(\mu \mathrm{g} \mathrm{chl} a)^{-1} \mathrm{~d}^{-1}$ (not shown). Water column integrated production (0 to $80 \mathrm{~m}$ ) ranged from $195 \mathrm{mg} \mathrm{C} \mathrm{m}^{-2} \mathrm{~d}^{-1}$ in March 1993 to $281 \mathrm{mg} \mathrm{C} \mathrm{m}^{-2} \mathrm{~d}^{-1}$ in February 1994. The rates of primary production from 1 in situ $(7 \mathrm{~h})$ incubation, after scaling the rates to $24 \mathrm{~h}$ (Wong et al. 1995),
Fig. 1 Vertical profiles of size-fractionated primary production at OSP unless stated otherwise: (A) 14 March 1993 on deck, (B) 15 March on deck, (C) 14 March 1993 in situ ( $\mathrm{g} \mathrm{C} \mathrm{C} \mathrm{l}^{-1} \mathrm{~d}^{-1}$; from $7 \mathrm{~h}$ incubation scaled to $24 \mathrm{~h}$; after Wong et al. 1995). (D) 13 February 1994 on deck at Station P23. Error bars represent $\bar{X} \pm$

$1 \mathrm{SE}$ for total production $(>0.2 \mu \mathrm{m})$
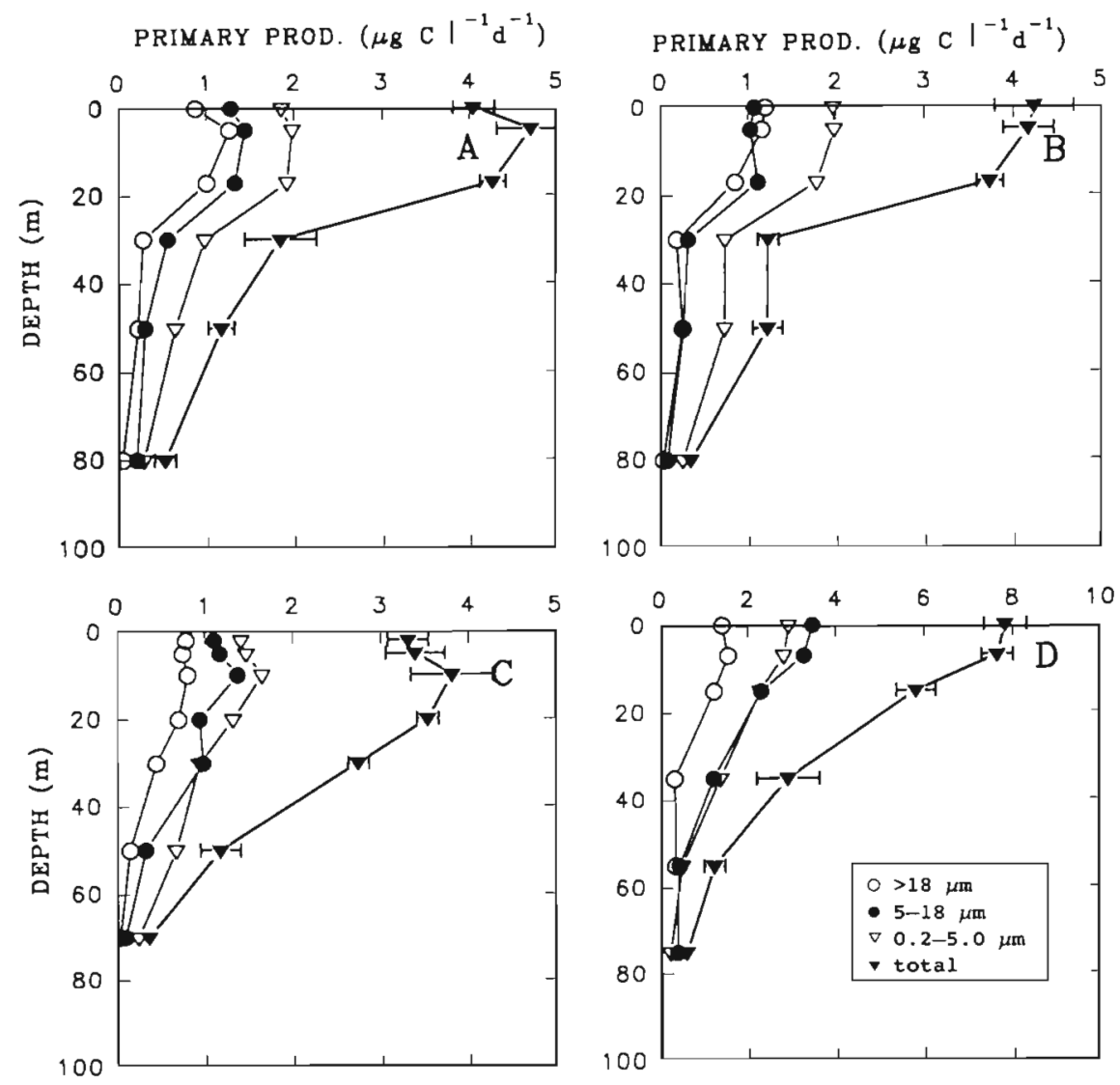
were comparable to the rates derived from concurrent $24 \mathrm{~h}$ on-deck incubations (Fig. 1A, C). There was evidence of slight photoinhibition in the samples from $100 \% I_{0}$ (Fig. 1). Although no detailed P:I experiments were conducted to assess the photosynthetic characteristics of the phytoplankton, a plot of chlorophyll normalized production against $\% I_{0}$ derived from an on-deck $24 \mathrm{~h}$ incubation performed on 14 March 1993 indicated that the maximum photosynthetic rate was attained at $30 \% I_{0}$ (ca $120 \mu \mathrm{mol}$ photons $\mathrm{m}^{-2} \mathrm{~s}^{-1}$; Fig. 2 ). From the initial slope of the P:I plot (Fig. 2), $\alpha$ was $0.012 \pm 0.003 \mathrm{mg} \mathrm{C}$ (mg chl a) $)^{-1} \mu$ mol quanta $\mathrm{m}^{-2} \mathrm{~s}^{-1}$.

In March 1993, in 3 primary production experiments (Fig. 1) the $<5 \mu \mathrm{m}$ size fraction made the largest contribution to primary production accounting for between ca 40 and $55 \%$ of total production (Table 1). The 5 to $18 \mu \mathrm{m}$ fraction and the $>18 \mu \mathrm{m}$ fractions contributed between 25 and $40 \%$, and $<20 \%$, respectively. In February 1994 , the 0.2 to $5 \mu \mathrm{m}$ and the 5 to $18 \mu \mathrm{m}$ fractions made equal contributions to production of around $40 \%$ (Table 1). The relative partitioning of primary production between the size classes concurred with that observed for chlorophyll at this time (Boyd et al. 1995). In both winter 1993 and 1994, there was little variation in the partitioning of primary production between these size classes with depth (Fig. 1).

Rates of bacterial production showed some interannual variability, with rates in winter 1993 being around 2 -fold lower than in winter 1994 when rates of $>0.8 \mathrm{pM}$ thymidine incorporated $\mathrm{h}^{-1}$ were recorded (Fig. 3). In both years, there was little variation in bacterial production with depth over the upper water column. Conversion of these rates of thymidine incorporation into units of carbon after Kirchman et al. (1993) yielded values of bacterial carbon production of between 0.3 and

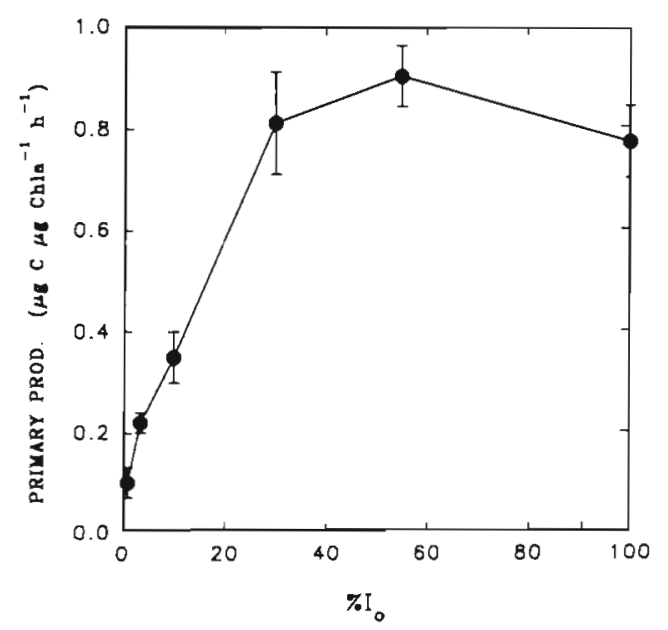

Fig. 2. Data from 14 March 1993 on deck normalized prmary production experiment plotted against $\% I_{0}$. Average $I_{0}$ for 14 March was $>400 \mu \mathrm{mol}$ photons $\mathrm{m}^{-2} \mathrm{~s}^{-1}$

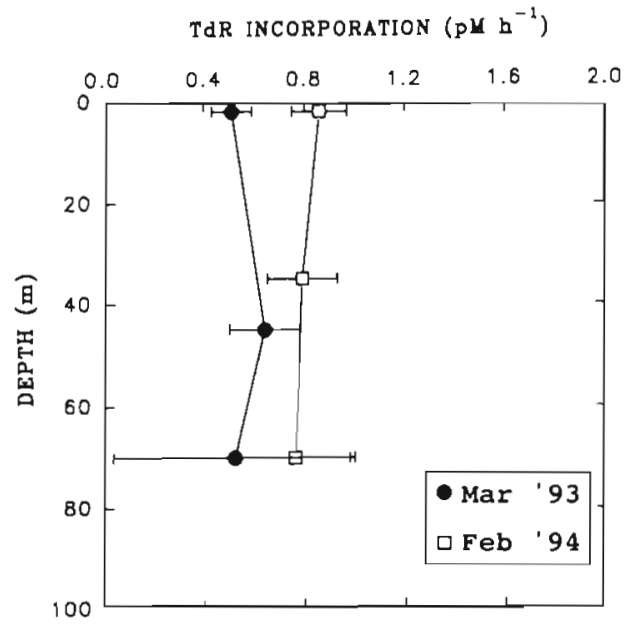

Fig. 3. Vertical profiles of bacterial production at OSP on 15 March 1993 and at P23 on 13 February 1994

Table 1 Estimates of partitioning of primary production between size fractions expressed as a percentage of total production. A, B and C refer to profiles in Fig. 1

\begin{tabular}{|lccc|}
\hline Date & \multicolumn{3}{c|}{ Size class } \\
& $>18 \mu \mathrm{m}$ & 5 to $18 \mu \mathrm{m}$ & 0.2 to $5.0 \mu \mathrm{m}$ \\
\hline March 1993 (A) & 20.3 & 24.6 & 55.1 \\
March 1993 (B) & 19.1 & 31.4 & 49.5 \\
March 1993 (C) & 21.5 & 36.4 & 42.1 \\
February 1994 & 21.4 & 41.3 & 37.3 \\
\hline
\end{tabular}

$0.8 \mu \mathrm{g} \mathrm{Cl}^{-1} \mathrm{~d}^{-1}$, which were $<10$ and $25 \%$ of the rate of primary production in the upper water column in winter 1993 and 1994, respectively.

Apparent algal growth rate $(\mu)$ and microzooplankton grazing mortality $(g)$ were calculated from the intercept with the $x$-axis and slope of regression lines obtained from dilution experiments (Fig. 4). No chlorophyll was detected in the $<0.2 \mu \mathrm{m}$ diluent at time zero,

Table 2. Apparent algal growth rates $(\mu)$, grazer mortality (g) and net algal growth rates $(\mu-g)$ from dilution experiments at OSP (March 1993) and P23 (February 1994). $\mu^{\text {d }}$ denotes phytoplankton growth rates calculated from column integrated primary production/column integrated biomass (converted from chlorophyll to carbon using a ratio of 50)

\begin{tabular}{|lcc|}
\hline Rate process & 1993 & 1994 \\
\hline$\mu$ & 0.21 & 0.23 \\
$g$ & 0.21 & 0.17 \\
$\mu-g$ & 0 & 0.06 \\
$\mathrm{r}^{2}$ (regression) & 0.77 & 0.71 \\
$\mu^{a}$ & 0.16 & 0.23 \\
\hline
\end{tabular}



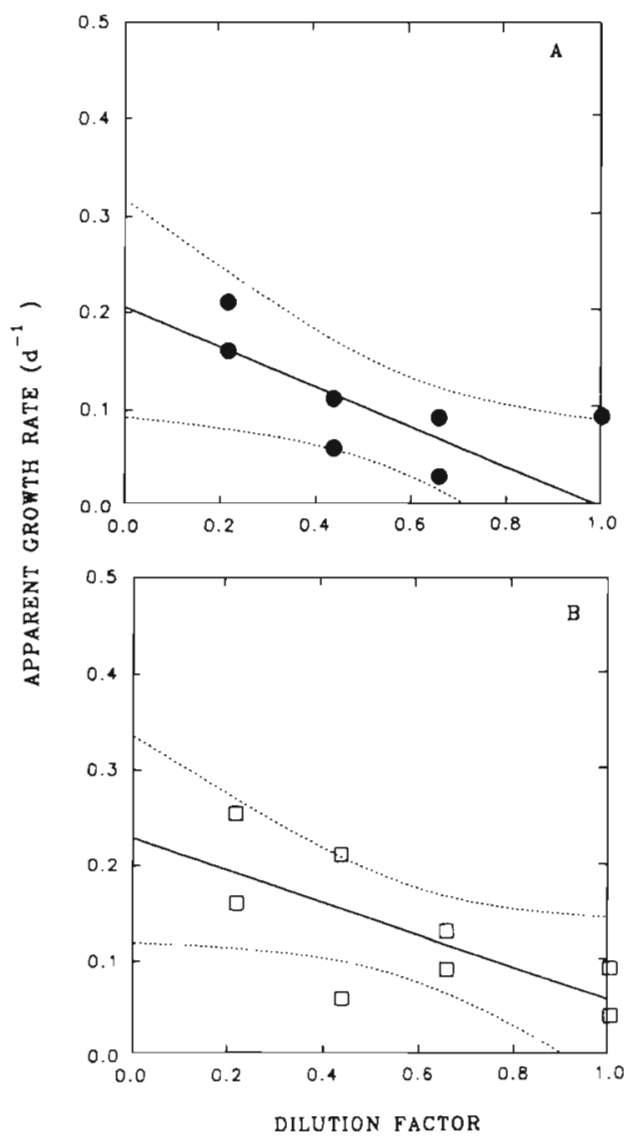

Fig. 4. Results of on-deck dilution experiments carried out on: (A) 14 March 1993 at OSP (B) 14 February 1994 at Station P23. Lines represent best linear fit to the data, dashed lines $=95 \%$ confidence interval

or after a $24 \mathrm{~h}$ incubation. The magnitudes of $\mu$ and $g$ were comparable between years, with $\mu$ of around $0.2 \mathrm{~d}^{-1}$ and $g$ of around $0.2 \mathrm{~d}^{-1}$ (Table 2). Thus, $\mu-g$ was close to zero in both years (Table 2).

The results of a $5 \mathrm{~d}$ iron enrichment experiment at a range of irradiances $\left(10,20,30 \% I_{0}\right)$ suggested little

Table 3. Chlorophyll concentrations $\left(\mu \mathrm{g} \mathrm{l}^{-1}\right)$ for 3 size classes over the duration of an iron enrichment experiment. Carboy: $\mathrm{A}=$ control, no $\mathrm{Fe}$ addition, $30 \% I_{0} ; \mathrm{B}=$ control, no Fe addi tion, $10 \% I_{0} ; \mathrm{C}=4 \mathrm{nM} \mathrm{Fe}, 30 \% I_{0} ; \mathrm{D}=4 \mathrm{nM} \mathrm{Fe}, 20 \% I_{0}$ a and $\mathrm{E}=4 \mathrm{nM} \mathrm{Fe}, 10 \% I_{0}$

\begin{tabular}{|c|c|c|c|c|c|}
\hline Time (d) & A & B & $\begin{array}{c}\text { Carboy } \\
\text { C }\end{array}$ & $\mathrm{D}$ & E \\
\hline 0 & 0.27 & 0.27 & 0.25 & 0.25 & 0.24 \\
\hline 1 & 0.29 & 0.25 & 0.23 & 0.25 & 0.27 \\
\hline 2 & 0.27 & 0.28 & 0.23 & 0.30 & 0.28 \\
\hline 3 & 0.31 & 0.29 & 0.20 & 0.27 & 0.25 \\
\hline 4 & 0.27 & 0.28 & 0.25 & 0.31 & 0.26 \\
\hline 5 & 0.29 & 0.31 & 0.24 & 0.27 & 0.32 \\
\hline
\end{tabular}

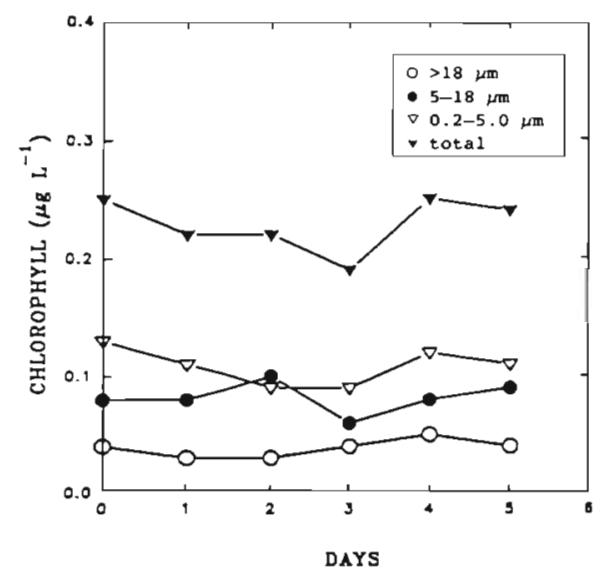

Fig. 5. Time series of changes in chlorophyll at $30 \% I_{0}$ during February 1994 at Station P23 in 3 size fractions of phytoplankton in response to the addition of $4 \mathrm{nM}$ dissolved iron at $t=0$

change in total chlorophyll concentrations in both the control and iron-enriched carboys for the duration of the $5 \mathrm{~d}$ incubations (Table 3 ). In addition, there was no change in the partitioning of chlorophyll between 3 size fractions of phytoplankton during the experiment (Fig. 5).

\section{DISCUSSION}

\section{Comparison with previous OSP winter primary production data}

The rates of water column integrated primary production observed in winter 1993 and 1994 ranged from 195 to $281 \mathrm{mg} \mathrm{C} \mathrm{m}^{-2} \mathrm{~d}^{-1}$ and were comparable to the winter rates reported by other investigators. Parsons \& Anderson (1970) measured production of $245 \mathrm{mg} \mathrm{C} \mathrm{m}^{-2}$ $\mathrm{d}^{-1}$ in March, and McAllister (1961) reported rates of primary production of $<100 \mathrm{mg} \mathrm{C} \mathrm{m}{ }^{-2} \mathrm{~d}^{-1}$ in March. Wong et al. (1995) measured rates of in situ production of 226 and $340 \mathrm{mg} \mathrm{C} \mathrm{m}^{-2} \mathrm{~d}^{-1}$ on consecutive days in February 1989 and of $230 \mathrm{mg} \mathrm{C} \mathrm{m}^{-2} \mathrm{~d}^{-1}$ in November 1984. The general agreement between the magnitude of the water column integrated primary production is encouraging since the majority of these previous estimates were obtained during short-term $(<8 \mathrm{~h})$ incubations and then scaled to obtain a daily rate. The present study also provided a comparison between production rates derived from short-term in situ incubations scaled to daily production after Wong et al. (1995) and a concurrent $24 \mathrm{~h}$ on-deck incubation. The results suggest that the techniques were comparable, yielding column integrated production of 217 and $195 \mathrm{mg} \mathrm{C} \mathrm{m}^{-2} \mathrm{~d}^{-1}$ for the in situ and on-deck techniques, respectively. 
As rates of primary production measured using the ${ }^{14} \mathrm{C}$ technique are thought to measure net primary production over longer time periods, such as $24 \mathrm{~h}$ (e.g. Laws 1990), the data obtained suggest that considerable net primary production does take place during the winter at OSP. In contrast, the primary production mandala presented by Parsons \& Lalli (1988) indicated that the average water column PAR is below the compensation light intensity $\left(0.13 \mathrm{ly} \mathrm{h}^{-1}=0.01 \mathrm{~mol}\right.$ quanta $\mathrm{h}^{-1}$ ) calculated by Parsons \& LeBrasseur (1968) for December and January, but that there is some net primary production in February and November. The data from the present study and from Wong et al. (1995) suggest that net primary production is significant in February and November and would be required to decrease considerably in January and December to result in no net primary production.

\section{Comparison with NE subarctic Pacific modelling simulations}

Although based on a limited data set, observed rates of winter primary production (195 to $281 \mathrm{mg} \mathrm{C} \mathrm{m}^{-2} \mathrm{~d}^{-1}$ ) were up to 2 times lower than predicted for winter from Fasham's (1995) simulations of the annual cycle at OSP (280 to $>400 \mathrm{mg} \mathrm{C} \mathrm{m}^{-2} \mathrm{~d}^{-1}$ ) but were more comparable to those estimates from Frost's (1993) simulation (200 to $>300 \mathrm{mg} \mathrm{C} \mathrm{m}^{-2} \mathrm{~d}^{-1}$ ). Frost's (1987) parameterization of the maximum photosynthetic rate $\left(P_{\mathrm{B} \max }\right)$ and photosynthetic efficiency $(\alpha)$ yielded winter values of $17 \mathrm{mg}$ $\mathrm{C}(\mathrm{mg} \mathrm{chl} \mathrm{a})^{-1} \mathrm{~d}^{-1}$ and $0.075 \mathrm{mg} \mathrm{C}(\mathrm{mg} \mathrm{chl} \mathrm{a})^{-1} \mu \mathrm{mol}$ quanta $\mathrm{m}^{-2} \mathrm{~s}^{-1}$ for $P_{\mathrm{B} \max }$ and $\alpha$, respectively, which were similar to, and 6 -fold higher than, respectively, those observed in the present study. In Fasham's model (1995), a value of $\alpha\left[0.052 \mathrm{mg} \mathrm{C}(\mathrm{mg} \mathrm{chl} \mathrm{a})^{-1} \mu \mathrm{mol}\right.$ quanta $\mathrm{m}^{-2} \mathrm{~s}^{-1}$ l was 4 -fold higher than that observed in the present study. From these different model parameterizations for photosynthetic characteristics it is not at present clear why the predicted winter areal primary production estimates from Frost (1993) are closer to those of the present study than to those of Fasham (1995).

\section{Comparison with previous OSP summer rate process data}

No other winter data from OSP are available for phytoplankton growth, microzooplankton grazing, size-fractionated production, photosynthetic characteristics or bacterial production. However, a comparison with data obtained in the late spring and early summer during the SUPER program suggests that the winter rates of all of these measurements are depressed relative to summer (Table 4). Apparent phytoplankton growth and microzooplankton grazing rates from the present study (Table 4) were at the lower end of the range of estimates measured by Landry et al. (1993) and are almost 2-fold less than mean summer values for both growth and grazing measurements (Landry et al. 1993). Net algal growth $(\mu-g)$ is close to zero in the present study as compared to a mean of 0.16 during summer (Landry et al. 1993). Rates of maximum chlorophyll-specific assimilation. ratio were 3 to 4 times lower for winter than those

Table 4. A comparison of winter and summer rate processes and environmental factors at OSP

\begin{tabular}{|c|c|c|}
\hline Parameter & Winter & Summer \\
\hline Primary production $\left(\mathrm{mg} \mathrm{C} \mathrm{m}^{-2} \mathrm{~d}^{-1}\right)$ & 195 to $281(n=4)$ & $\begin{array}{c}727^{a} \\
358 \text { to } 1420^{\varsigma}(=25)\end{array}$ \\
\hline Mixed layer depth (m) & 100 & $>50$ to $<20^{a}$ \\
\hline Chlorophyll (mg chl $\mathrm{a} \mathrm{m}^{-2}$ ) & 20 to $28(0$ to $80 \mathrm{~m})$ & 19.7 to $31.7^{b}(0$ to $80 \mathrm{~m})$ \\
\hline PAR (mol photons $d^{-i}$ ) & $<20$ & 20 to $50 r$ \\
\hline Water temperature $\left({ }^{\circ} \mathrm{C}\right)$ & 5.5 & $>8^{a}$ \\
\hline Normalized primary production [mg C $\left.(\mathrm{mg} \mathrm{chl} \mathrm{a})^{-1} \mathrm{~d}^{-1}\right]$ & $<10$ to 23 & 35 to $>100^{d}$ \\
\hline Bacterial production $\left(\mu \mathrm{g} \mathrm{Cl}^{-1} \mathrm{~d}^{-1}\right.$ ) & 0.3 to 0.9 & 0.5 to $2.0^{\mathrm{e}}$ \\
\hline Microzooplankton grazing mortality $\left(\mathrm{d}^{-1}\right)$ & 0.17 to 0.21 & $0.31^{\mathrm{f}}(0.12$ to 0.71$)(\mathrm{n}=23)$ \\
\hline Algal growth rate $\left(\mathrm{d}^{-1}\right)$ & 0.21 to 0.23 & $0.42^{f}(-0.05$ to 0.72$)(\mathrm{n}=23)$ \\
\hline Net algal growth $(\mu-g)\left(d^{-1}\right)$ & 0 to 0.06 & $0.16^{1}(-0.39$ to 0.66$)(n=27)$ \\
\hline \multicolumn{3}{|l|}{ "Mean production, 1971 mixed layer depth data ${ }_{i}$ Frost (1993) } \\
\hline \multicolumn{3}{|l|}{ bBooth et al. (1993) } \\
\hline \multicolumn{3}{|c|}{ 'Range of areal primary production, range of incident irradiance; Welschmeyer et al. (1993) } \\
\hline \multicolumn{3}{|c|}{${ }^{1}$ Range of maximum chlorophyll-specific assimilation rates in the vicinity of the surface from Welschmeyer et al. (1993) } \\
\hline \multicolumn{3}{|c|}{ 'Range of 3 cruises (May, August, September); Kirchman et al. (1993) } \\
\hline \multicolumn{3}{|c|}{${ }^{f}$ Range of 3 cruises (May, June, August); Landry et al. (1993) } \\
\hline
\end{tabular}


observed for summer (Table 4). Bacterial production rates were around 2 -fold less for the present study than observed by Kirchman et al. (1993), but display a similar 2 -fold range of values during winter and summer (Table 4).

Miller et al. (1991), in discussing the SUPER synthesis, questioned the nature of the relationship between phytoplankton and micrograzer standing stacks at lower irradiances and temperatures associated with winter. They also suggested that rates of primary production would be lower, but that the phytoplankton should keep on growing and that the micrograzers should keep the phytoplankton stocks in check. The findings of Boyd et al. (1995), although based on a limited number of observations, suggested that the winter standing stocks of the autotrophic phytoplankton and microheterotrophs were similar to those observed in spring and summer at OSP, but that the standing stocks of mesozooplankton were lower during winter than in summer. Despite the relatively high winter standing stocks of autotrophs and heterotrophs, the magnitude of rate measurements in winter are depressed (Table 4), indicating that the turnover of autotrophic biomass is lower in winter than in summer. From the physical, chemical and biological data available, it is possible, however, to assess what factors may be responsible for the reduced turnover of standing stocks during this period.

\section{Factors controlling rate processes}

In late spring and early summer phytoplankton growth rates were reported to be as high as available light and temperature permit (Miller et al. 1991 and references therein). In addition, at OSP the growth rates of large diatoms have been shown to be enhanced by the addition of trace amounts of dissolved iron in August (Martin et al. 1989, Coale 1991) and late May (P. W. Boyd, D. L. Muggli, D. V. Varela, R. Chretien, K. J. Orians \& P. J. Harrison unpubl.). Thus, factors which could limit phytoplankton production during the winter period include micronutrients, irradiance, temperature and grazing. The results of the iron/irradiance extended bioassay (Table 3) suggest that, unlike late spring when iron limitation of the growth rates of large diatoms was observed (Boyd et al., unpubl.), iron does not appear to limit phytoplankton growth during winter. From Banse (1991), the maximum phytoplankton growth rate at winter temperatures at $\operatorname{OSP}\left(6^{\circ} \mathrm{C}\right)$ is around $0.5 \mathrm{~d}^{-1}$ (using the $1 / 2$ maximum curve and with the caveat that it is appropriate to use this curve for oceanic species) and this may be contrasted with the maximum phytoplankton growth rate at summer temperatures at OSP $\left(11^{\circ} \mathrm{C}\right)$ of around $0.7 \mathrm{~d}^{-1}$. Apparent algal growth rates from dilution experiments (Table 2) and calculated from column integrated biomass production (Table 2) indicate that phytoplankton growth rates are ca $50 \%$ of maximum microalgal growth rate at $6^{\circ} \mathrm{C}$ and therefore phytoplankton growth rates were unlikely to have been temperature limited.

While relatively high incident irradiances were noted in March 1993, in general irradiances in winter at OSP are lower than in summer (Frost 1993). In addition, the depth of the mixed layer is greater in winter than in summer (Tabata 1989); thus, daily mean irradiance for cells in the water column is considerably lower in winter. A comparison of chlorophyll normalized rates of column integrated primary production indicates that the values were almost $2 / 3$ lower than those observed during summer by the SUPER group (Table 4); winter values of 10 to $20 \mathrm{mg} \mathrm{C} \mathrm{mg} \mathrm{chl} \mathrm{a} \mathrm{m-1}$ $\mathrm{d}^{-1}$ were obtained at daily irradiance totals of $<20 \mathrm{~mol}$ photons $\mathrm{d}^{-1}$. Thus, the observed low rates of column integrated primary production (Fig. 1) were consistent with the reduced apparent growth rates for phytoplankton in winter (Table 2). However, the nature of the relationship between normalized production and daily irradiance is not clear; Welschmeyer et al. (1993; see Fig. 6) observed no significant relationship between maximum carbon uptake per unit chlorophyll and daily irradiance or between depth integrated primary production and daily surface irradiance (Welschmeyer et al. 1993; see Fig. 11). They reported a range of column integrated production values from $<0.4$ to $>1 \mathrm{~g} \mathrm{C} \mathrm{m}^{-2} \mathrm{~d}^{-1}$ at $<20 \mathrm{~mol}$ photons $\mathrm{m}^{-2} \mathrm{~d}^{-1}$, a daily total irradiance similar to that noted in the present study. In addition, Wong et al. (1995) reported a $50 \%$ increase in integrated production between consecutive days in November 1989. Despite these uncertainties, winter chlorophyll normalized rates, which are intrinsic measurements of growth independent of grazing activity, are depressed, and it is most likely that phytoplankton growth during winter is limited by available irradiance and thus algal iron demand in winter is reduced relative to other seasons.

Although algal growth rates were considerably less than $\mu_{\max }$ (based on Banse's 1/2 maximum curve) at this time of year, grazing mortality was closely coupled to algal growth rates (Table 2) suggesting that the 2 processes remain closely coupled during winter. The grazing rates of protists such as ciliates are known to be dependent on food concentrations (Jonnson 1986, Pierce \& Turner 1992). However, winter phytoplankton standing stocks, and hence food concentrations, are similar to those noted in summer (Table 4), yet microheterotroph grazing rates are reduced in winter as compared to summer (Table 4). It is possible that either the reduced winter microzooplankton grazing rates 
are not due to food concentrations but to some other factor such as temperature, or there may be a food threshold effect such that any increase in phytoplankton biomass due to increases in the magnitude of primary production are consumed by the microheterotrophs. The reduced turnover of phytoplankton carbon in winter is consistent with the latter notion. Although both Frost (1993) and Fasham (1995) used herbivore grazing thresholds of ca $10 \mathrm{mg} \mathrm{C} \mathrm{m}^{-3}$ in their models, little is known about the changes in the growth response of open ocean microzooplankton with respect to changes in food concentration.

Reduced microzooplankton grazing rates may also be due in part to temperature effects. Muller \& Geller (1993) reported that for several species of freshwater ciliates not under food limitation the growth rates (and therefore presumably the grazing rates) for certain species doubled in response to a temperature increase from 6 to $12^{\circ} \mathrm{C}$ (comparable to the range noted at OSP over the annual cycle). A similar temperature response by open ocean microzooplankton (in the absence of food limitation) would explain the differences between winter and summer grazer mortality rates without having to invoke grazing thresholds.

While grazing mortality and algal growth are closely coupled, resulting in algal stocks remaining constant and similar to those observed in summer (Boyd et al. 1995), how do micrograzers maintain their relatively high standing stocks in winter if their grazing and hence growth rates are depressed? Miller et al. (1991) invoked low physical mixing to prevent dispersal of cells as a mechanism to permit the maintenance of high winter microzooplankton stocks, but did not consider predator control. The main predators of the microzooplankton are thought to be the mesozooplankton (Gifford 1993) which are present in low numbers at this time (McAllister 1961, Fulton 1978, Miller et al. 1984). Thus, it might be expected that the grazing pressure on the microzooplankton would also be reduced. Indeed, using summer microzooplankton grazing rates by mesozooplankton from OSP (Gifford 1993), scaled to winter mesozooplankton standing stocks, it is possible to estimate winter grazing on microzooplankton by mesozooplankton. Calculated winter clearance rates of 0.04 to 0.13 and 0.05 to 0.28 of the upper water column $\mathrm{d}^{-1}$ by the mesozooplankton population for 1993 and 1994, respectively, constitute the daily removal of $<13$ and $<28 \%$ of microzooplankton stocks (Table 5). This calculation does not consider any temperature related change in grazing rate due to winter conditions. An estimate of the feeding rate of the mesozooplankton in winter using Frost's temperature dependent equation (1993; Eq. 10) in conjunction with data from the present study results in estimated feeding rates at $5^{\circ} \mathrm{C}$ of 0.029 to $0.035 \mathrm{mg} \mathrm{C}$ (mg
$C \mathrm{~m}^{-3} \mathrm{~J}^{-1} \mathrm{~d}^{-1}$, which are considerably lower than those estimates based on Gifford (1993). Both methods of estimation suggest that mesozooplankton grazing pressure in winter is low. In contrast to the low winter mesozooplankton grazing rates, Gifford (1993) reported that copepod grazing activities appeared to be sufficient to control microzooplankton stocks during late spring and early summer at OSP.

\section{Estimation of carbon turnover}

An assessment of the partitioning of autotrophic and heterotrophic carbon for winter standing stocks constructed by Boyd et al. (1995) indicates that the carbon demands of heterotrophic bacteria cannot be balanced unless the standing stocks of these heterotrophic groups are turning over more slowly than that of the carbon supply. In the case of bacteria, the low rates of bacterial production when compared to the bacterial biomass standing stocks from the present study (Boyd et al. 1995) indicate a pool with slow turnover. This agrees with Kirchman et al.'s (1993) observations of slow bacterial growth rates of $<0.1 \mathrm{~d}^{-1}$ during summer at OSP. Kirchman et al. (1993) proposed that bacterial growth rates were limited by substrate supply and water temperature. It is likely that the reduced water temperatures and potentially lower substrate supply from phytoplankton associated with winter conditions results in turnover times which are even slower than those observed by Kirchman et al. (1993), and are

Table 5. Calculation of potential mesozooplankton clearance rates on microzooplankton based on winter abundance data (ind $\mathrm{m}^{-2}$ for 0 to $100 \mathrm{~m}$ ) and summer mesozooplankton. clearance rates (ind. $\mathrm{l}^{-1}$ copepods $\mathrm{d}^{-1}$ ). N. Neocalanus. No attempt was made to scale the summer grazing rates to winter temperatures at OSP (or prey concentrations). Values in parentheses indicate ind. $\mathrm{m}^{-3}$ Zooplankton: winter mesozooplankton clearance rates $\left(\mathrm{mg} \mathrm{C}\left(\mathrm{mg} \mathrm{C} \mathrm{m}^{-3}\right)^{-1} \mathrm{~d}^{-1} \mid\right.$ calculated using Eq. (10) in Frost (1993) in conjunction with data on mesozooplankton and herbivore standing stock data

\begin{tabular}{|c|c|c|}
\hline Species & 1993 & 1994 \\
\hline \multicolumn{3}{|c|}{ Winter (Boyd et a). 1995) } \\
\hline N. plumchrus CV & $1.3(0.013)$ & CIV 29.4 (0.294) \\
\hline N. cristatus CV & $13.3(0.133)$ & \\
\hline \multicolumn{3}{|l|}{ Summer (Gifford 1993) } \\
\hline N. plumchrus CV & $0.17-0.94$ & \\
\hline N. cristatus CV & $0.37-0.80$ & \\
\hline \multicolumn{3}{|l|}{ Winter } \\
\hline $\begin{array}{l}\% \text { of upper water } \\
\text { column cleared } d^{-1}\end{array}$ & $4.2-13$ & $5-27.6$ \\
\hline Zooplankton & $0.029-0.035$ & \\
\hline
\end{tabular}


therefore the probable modes of control of bacterial production during the winter period. The bacterial carbon turnover times $\left(<0.05 \mathrm{~d}^{-1}\right)$ are considerably lower than those for picophytoplankton $\left(0.15\right.$ to $\left.0.25 \mathrm{~d}^{-1}\right)$ in winter If the main grazers of picoplankton, heterotrophic flagellates, do not discriminate between heterotrophic and autotrophic prey, then it appears difficult to reconcile these differences in picoplankton turnover times. This imbalance may be resolved if the microzooplankton at OSP graze on picophytoplankton but not on heterotrophic bacteria.

\section{CONCLUSIONS}

(1) The findings of this study and Boyd et al. (1995) confirm the model of Evans \& Parslow (1985) and the hypothesis of Miller et al, (1991) who emphasized the importance of mid-winter phytoplankton growth rates in maintaining sufficient winter microzooplanktonic herbivores to graze down any increase in the standing stock of phytoplankton.

(2) In winter at OSP, there is a low turnover of standing stocks relative to summer. Autotrophic standing stocks remain constant as phytoplankton growth and grazing mortality appear to be balanced. Low grazing pressure by mesozooplankton on microzooplankton permits relatively high microzooplankton standing stocks in spite of reduced microzooplankton grazing rates. It is therefore likely that reduced mesozooplankton stocks in the upper water column during winter due to the ontogenetic life cycle of the dominant mesozooplankton are important in preventing a spring phytoplankton bloom.

(3) Both phytoplankton and, by implication, microzooplankton appear to be growing at ca $50 \%$ of $\mu_{\max }$ during winter. The factors controlling winter rate processes appear to be available irradiance for primary production, water temperature and/or available prey for microzooplankton grazing, and substrate supply and/or water temperature for bacterial production. More information is required on the role of these processes on controlling rate processes within the pelagic microbial food web at OSP.

Acknowledgements. We acknowledge Captain Anderson, the officers and crew of the DFO research vessel 'John P Tully', technical assistance on board the ship from $\mathrm{H}$. McClean (UBC), T Soutar, R. Bellegay (Center for Ocean Climate Chemistry, IOS Sidney, Canada) and R. Bingham (Ocean Physics, IOS Sidney, Canada). We thank K. Banse, S. Strom and 3 anonymous reviewers for their helpful comments on the manuscript. This research was performed as part of the Canadian JGOFS Program. Principal support for Canadian JGOFS comes from the Natural Sciences and Engineering Research Council and from the Department of Fisheries and Oceans, Canada.

\section{LITERATURE CITED}

Banse K (1990) Does iron really limit phytoplankton production in the offshore subarctic Pacific? Limnol Oceanogr 35: $772-775$

Banse K (1991) Rates of phytoplankton cell division in the field and in iron enrichment experiments. Limnol Oceanogr $36: 1886-1898$

Bell RT (1993) Estimating production of heterotrophic bacterioplankton via incorporation of tritiated thymidine. In: Kemp PF, Sherr BF. Sherr EB, Cole JJ (eds) Handbook of methods in aquatic microbial ecology. Lewis Publ, Boca Raton, FL, p 495-503

Boyd PW, Strom S, Whitney FA, Doherty S, Wen ME, Harrison PJ, Wong CS (1995) The NE subarctic Pacific in winter: I. Biological standing stocks. Mar Ecol Prog Ser 128:11-24

Coale KH (1991) Effects of iron, manganese, copper and zinc enrichments on productivity and biomass in the subarctic Pacific. Limnol Oceanogr 36:1851-1864

Evans GT, Parslow JS (1985) A model of annual plankton cycles. Biol Oceanogr 3:327-347

Fasham MJR (1995) Variations in the seasonal cycle of biological production in subarctic oceans: a model sensitivity analysis. Deep Sea Res I 42:1111-1149

Frost BW (1987) Grazing control of phytoplankton stock in the open subarctic Pacific Ocean: a model assessing the role of mesozooplankton, particularly the large calanoid copepods, Neocalanus spp. Mar Ecol Prog Ser 39:49-68

Frost BW (1991) The role of grazing in nutrient-rich areas of the open sea. Limnol Oceanogr 36:1616-1630

Frost BW (1993) A modelling study of processes regulating plankton standing stock and production in the open subarctic Pacific Ocean. Prog Oceanogr 32:17-56

Fulton JD (1978) Seasonal and annual variations of net zooplankton at Ocean Station P, 1965-1976. Can Fish Mar Serv Data Rep 49

Furhman JA, Azam F (1982) Thymidine incorporation as a measure of heterotrophic bacterioplankton production in marine surface waters: evaluation and field results. Mar Biol 66:109-120

Gifford DJ (1993) Protozoa in the diets of Neocalanus spp. in the oceanic subarctic Pacific Ocean. Prog Oceanogr 32: 223-237

Joint IR, Pomroy AJ (1983) Production of picoplankton and small nanoplankton in the Celtic Sea. Mar Biol 77: $19-27$

Joint I, Pomroy A, Savidge G, Boyd P (1993) Size-fractionated primary productivity in the northeast Atlantic in May-July 1989. Deep Sea Res II 40:423-440

Jonsson PR (1986) Particle size selection, feeding rates and growth dynamics of marine planktonic oligotrichous ciliates (Ciliophora: Oligotrichina). Mar Ecol Prog Ser 33: $265-277$

Kirchman DL, Keil RG, Simon M, Welschmeyer NA (1993) Biomass and production of heterotrophic bacterioplankton in the oceanic subarctic Pacific. Deep Sea Res 40:967-988

Landry MR (1993) In: Kemp PF, Sherr BF, Sherr EB, Cole JJ (eds) Estimating rates of growth and grazing mortality of photoautotrophic plankton by dilution. Handbook of methods in aquatic microbial ecology. Lewis Publ, Boca Raton, FL, p 715-722

Landry MR, Gifford DJ, Kirchman DL, Wheeler PA, Monger BC (1993) Direct and indirect effects of grazing by Neocalanus plumchrus on plankton community dynamics in the subarctic Pacific. Prog Oceanogr 32:205-222

Laws EA (1990) Photosynthetic quotients, new production 
and net community production in the open ocean. Deep Sea Res 38:143-167

Li WKW (1990) Particles in particle free seawater: growth of ultraplankton and implications for dilution experiments. Can J Fish Aquat Sci 47:1258-1269

McAllister CD (1961) Zooplankton studies at Ocean Weather Station ' $\mathrm{P}$ ' in the north-east Pacific Ocean. J Fish Res Bd Can 18:1-29

Martin JH, Fitzwater SE, Gordon RM, Broenkow WW (1989) VERTEX: Phytoplankton/iron studies in the Gulf of Alaska. Deep Sea Res 36:649-680

Martin JH, Gordon RM (1988) Northeast Pacific iron distributions in relation to plankton productivity. Deep Sea Res 35: $177-196$

Miller CB (1993) Pelagic production processes in the Subarctic Pacific. Prog Oceanogr 32:1-15

Miller CB, Frost BW, Batchelder HP, Clemons MJ, Conway RE (1984) Life history of large, grazing copepods in the subarctic Pacific Ocean Gyre: Neocalanus plumchrus, Neocalanus cristatus and Eucalanus bungii in the northeast Pacific. Prog Oceanogr 13:201-243

Miller CB, Frost BW, Wheeler PA, Landry MR, Welschmeyer N, Powell TM (1991) Ecological dynamics in the subarctic Pacific, a possibly iron limited system. Limnol Oceanogr 36:1600-1615

Muller H, Geller W (1993) Maximum growth rates of aquatic ciliated protozoa: the dependence of body size and temperature reconsidered. Arch Hydrobiol 126:315-327

Parslow JS (1981) Phytoplankton-zooplankton interactions: data analysis and modelling (with particular reference

This article was presented by D. K. Stoecker (Senior Editorial Advisor), Cambridge, Maryland, USA to Ocean Station Papa $\left[50^{\circ} \mathrm{N}, 145^{\circ} \mathrm{W}\right]$ and controlled ecosystem experiments). $\mathrm{PhD}$ thesis, University of British Columbia, Vancouver

Parsons TR, Anderson GC (1970) Large scale studies of primary production in the north Pacific Ocean. Deep Sea Res $17: 765-776$

Parsons TR, Lalli CM (1988) Comparative oceanic ecology of the plankton communities of the subarctic Atlantic and Pacific Oceans. Oceanogr mar Biol A Rev 26: $317-359$

Parsons TR, LeBrasseur RJ (1968) A discussion of some critical indices of primary and secondary production for largescale ocean surveys. CalCOFI Rep 12:54-63

Parsons TR, Maita Y, Laili CM (1984) A manual of chemical and biological methods for seawater analysis. Pergamon Press, Oxford, UK

Pierce RW, Turner JT (1992) Ecology of planktonic ciliates in marine food webs. Rev aquat Sci 6:139-181

Tabata S (1989) Trends and long term variability of ocean properties at Ocean Station $P$ in the north-east Pacific Ocean. Geophys Monogr 55:113-132

Welschmeyer N A, Strom S, Goericke R, DiTuillio G, Belvin B, Petersen W (1993) Primary production in the subarctic Pacific Ocean: Project SUPER. Prog Oceanogr 32: $101-135$

Wong CS, Whitney FA, Iseki K, Page JS, Zeng J (1995) Analysis of trends in primary production and chlorophyll-a over two decades at Ocean Station $\mathrm{P}\left(50^{\circ} \mathrm{N}, 145^{\circ} \mathrm{W}\right)$ in the subarctic Northeast Pacific Ocean. Can J Fish aquat Sci $121: 107-117$

Manuscript first received: January 15, 1995

Revised version accepted: June 1, 1995 